\title{
Modified Widal test using 2-mercaptoethanol for detecting anti-salmonella IgM in febrile patients
}

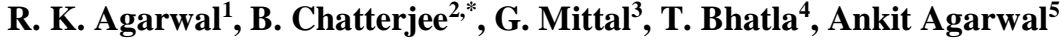 \\ ${ }^{1}$ Professor, ${ }^{2,3}$ Associate Professor, ${ }^{4}$ MBBS Intern, Dept. of Microbiology, Himalayan Institute of Medical Sciences, Dehradun, \\ Uttarakhand, ${ }^{5}$ Associate Professor, Dept. of Anesthesiology, All-India Institute of Medical Sciences, Rishikesh, \\ Uttarakhand, India
}

*Corresponding Author:

Email: doctorbiswaroopchatterjee@gmail.com

Received: $27^{\text {th }}$ April, 2018

Accepted: $30^{\text {th }}$ May, 2018

\begin{abstract}
Introduction: Despite limitations, the Widal test is widely used in resource-constrained settings because it is fast, inexpensive and user-friendly. Therefore, efforts continue to improve its diagnostic utility.

Aims: Using 2-mercaptoethanol (2-ME) to detect the IgM fraction of total agglutinins detected by the Widal test in the serum of febrile patients.

Materials and Methods: Single serum specimens were collected from 333 patients presenting to our hospital with fever. One aliquot of serum was tested by standard Widal test; a positive result was defined as simultaneous elevation of ' $\mathrm{O}$ ' and ' $\mathrm{H}$ ' titres to 1:80 or above. A second aliquot was simultaneously tested by a modified Widal test in which serum was diluted in isotonic saline with added 2-ME $(0.12 \mathrm{M})$ instead of in plain isotonic saline. Differences in titre between the two versions of Widal test were noted. A four-fold or greater reduction in titre upon testing with 2-ME, was considered evidence of specific IgM.

Results: Standard Widal test was positive in 55 (16.5\%) out of 333 patients. A $\geq 4$-fold reduction of ' $\mathrm{O}$ ' titre in modified Widal test was found in $38(69.1 \%)$ out of 55 cases, indicating the presence of specific IgM. A similar reduction of 'H' titre was seen in only $6(11 \%)$ out of 55 cases.

Conclusion: Simultaneous use of standard Widal test and modified Widal test with 2-ME allows the detection of specific IgM at a low cost. This can increase the diagnostic utility of the Widal test.
\end{abstract}

Keywords: Acute febrile illness, Typhoid fever, Serology, IgM, Laboratory diagnosis.

\section{Introduction}

Typhoid fever, caused by Salmonella enterica subsp. enterica Serotype Typhi (commonly known as Salmonella Typhi) is one of the commonest infectious diseases in the developing world. ${ }^{1,2}$ Its annual incidence in India has been estimated to be $760 / 100,000,{ }^{3}$ and up to $10 \%$ of all children living in urban slums can end up with the disease. ${ }^{4}$ The problem has been aggravated by the emergence of resistance to multiple antimicrobials. ${ }^{5}$

Laboratory diagnostic modalities include culture, nucleic acid amplification, and serological testing. ${ }^{5}$ Definitive diagnosis requires isolation of the organism from blood, bone marrow or other specimens. However, facilities for bacterial culture are not always available or affordable. Therefore, the need for a quick, affordable and user-friendly test is keenly felt. The Widal test, which was developed by George Ferdinand Widal in $1896,{ }^{6}$ does fulfill these criteria. The principle of the test is the visible agglutination of Salmonella antigen by specific antibody in the patient's serum.

Though the Widal test has been in use for more than a century, its value in the diagnosis of enteric fever is still debated. ${ }^{7}$ First of all, agglutinins take around a week to appear after the onset of illness in immunologically naïve individuals; therefore, the test is of practically no use in the first week of fever. Secondly, people who have been infected or immunized in the past, may develop an anamnestic response during an unrelated illness. A false-positive Widal test is known to occur in chronic liver disease, rheumatoid arthritis, myeloma, nephrotic syndrome and in febrile illnesses such as typhus and malaria. ${ }^{8,9}$ On the other hand, the antibody response may be dampened in relapse and after antimicrobial treatment; this may lead to false-negative Widal results. Since enteric fever is endemic in India, many healthy individuals have circulating antibodies due to repeated exposure to typhoid bacilli. A single Widal test is therefore considered to be of little use in diagnosis. A four-fold or greater rise in titre when the Widal test is repeated 710 days after the first, is considered diagnostic; however, it is seldom possible to wait that long for a definitive diagnosis.

A modified Widal test ${ }^{10-13}$ is available in which serum is first treated with 2-mercaptoethanol (2-ME) to inactivate IgM antibodies. A four-fold or greater fall in antibody titre after 2-ME treatment indicates the presence of IgM which is considered a marker of current or recent infection. The present study was therefore undertaken to look at the occurrence of specific IgM antibodies, as inferred from the reduction of ' $\mathrm{O}$ ' and ' $\mathrm{H}$ ' titres in the modified Widal test, in the sera of febrile patients testing positive by the standard Widal test. 


\section{Materials and Methods}

The study was conducted on serum specimens referred to our laboratory for the standard Widal test. These non-replicate specimens had been taken from 333 patients presenting with acute febrile illness during the two-month period from June 1, 2015 to July 31, 2015. For the purpose of this study, patient identity was kept anonymous. Standard Widal test was performed in Felix and Dreyer's tubes by standard technique. ${ }^{14}$

Modified Widal test with 2-mercaptoethanol (2$\mathrm{ME})$ : This test was done exactly the same way as the standard Widal test except that serum dilutions were made in isotonic saline to which 2-ME had been added to a final concentration of $0.12 \mathrm{M}$ (made by adding 9.37 $\mathrm{ml}$ of 2-ME to $1000 \mathrm{ml}$ of isotonic saline). Four-fold or greater reduction in titre compared to the standard test was considered indicative of specific IgM antibodies and counted as a positive result in the modified Widal test with 2-ME.

Salmonella antigen was obtained commercially from Span Diagnostics, India for both versions of the test.

\section{Results}

Fifty-five (16.5\%) of 333 serum specimens from febrile patients had both ' $O$ ' and ' $H$ ' titres $\geq 1: 80$ in the standard Widal test. Young adults in the age group of 15-29 years were affected most often with no significant sex difference (Table 1).

Antibody titres in the standard Widal test are presented in Table 2. Most patients had titres of 1:80 or $1: 160$; only a few had titres of $\geq 1: 320$.

The modified Widal test with $2-\mathrm{ME}$ led to a $\geq 4$ fold fall in ' $\mathrm{O}$ ' titre in $38(69 \%)$ specimens, indicating an important contribution of IgM to the 'O' antibody response (Table 3 ). In contrast, a $\geq 4$-fold fall in ' $\mathrm{H}$ ' antibody titre was seen in only $6(11 \%)$ of specimens, indicating that only a few subjects had a significant IgM response to ' $\mathrm{H}$ ' antigens (Table 4).

Table 1: Age and sex distribution of Widal-positive cases

\begin{tabular}{|l|c|c|c|}
\hline Age Group & \multicolumn{2}{|c|}{ Sex } & Total \\
\hline & Male & Female & \\
\hline$<15$ years & 9 & 0 & 9 \\
\hline 15-29 years & 12 & 12 & 24 \\
\hline 30-44 years & 4 & 9 & 13 \\
\hline$>45$ years & 4 & 5 & 9 \\
\hline Total & 29 & 26 & 55 \\
\hline
\end{tabular}

Table 2: Titres of ' $\mathrm{O}$ ' and ' $\mathrm{H}$ ' antibodies in standard Widal test

\begin{tabular}{|l|c|c|c|}
\hline \multicolumn{1}{|c|}{$\mathbf{T}_{\mathbf{O}}$} & \multicolumn{3}{|c|}{$\mathbf{T}_{\mathbf{H}}$} \\
\hline & $\mathbf{1 : 8 0}$ & $\mathbf{1 : 1 6 0}$ & $\geq \mathbf{1 : 3 2 0}$ \\
\hline $1: 80$ & 12 & 5 & 0 \\
\hline $1: 160$ & 9 & 16 & 2 \\
\hline$\geq 1: 320$ & 2 & 4 & 5 \\
\hline
\end{tabular}

Table 3: Reduction in titre of ' $O$ ' antibody in 2mercaptoethanol test

\begin{tabular}{|l|c|c|c|c|}
\hline $\begin{array}{c}\text { Standard } \\
\text { Widal } \\
\text { Titre }\end{array}$ & \multicolumn{2}{|c|}{ Reduction in 2-mercaptoethanol test } \\
\hline & $\begin{array}{c}\text { No } \\
\text { reduction }\end{array}$ & $\begin{array}{c}\text { Two- } \\
\text { fold }\end{array}$ & $\begin{array}{c}\text { Four- } \\
\text { fold }\end{array}$ & $\begin{array}{c}\text { Eight- } \\
\text { fold }\end{array}$ \\
\hline $1: 80$ & 9 & 5 & 3 & 0 \\
\hline $1: 160$ & 2 & 1 & 12 & 12 \\
\hline$\geq 1: 320$ & 0 & 0 & 8 & 3 \\
\hline
\end{tabular}

Table 4: Reduction in titre of 'H' antibody in 2mercaptoethanol test

\begin{tabular}{|l|c|c|c|c|}
\hline $\begin{array}{c}\text { Standard } \\
\text { Widal } \\
\text { Titre }\end{array}$ & \multicolumn{4}{|l|}{ Reduction in 2-mercaptoethanol test } \\
\hline & $\begin{array}{c}\text { No } \\
\text { reduction }\end{array}$ & $\begin{array}{c}\text { Two- } \\
\text { fold }\end{array}$ & $\begin{array}{c}\text { Four- } \\
\text { fold }\end{array}$ & $\begin{array}{c}\text { Eight- } \\
\text { fold }\end{array}$ \\
\hline $1: 80$ & 16 & 6 & 1 & 0 \\
\hline $1: 160$ & 4 & 19 & 2 & 0 \\
\hline$\geq 1: 320$ & 0 & 4 & 3 & 0 \\
\hline
\end{tabular}

\section{Discussion}

'O' agglutinin titres decreased four-fold or more in $69 \%$ of our specimens after 2-ME treatment. This is similar to the figure reported by Sendil et al. in a recent study on the modified Widal test using 2-ME. ${ }^{13}$ It is noteworthy that although ' $\mathrm{O}$ ' titre underwent a fourfold or greater decrease in the 2-ME Widal test in the majority of our specimens, they never became undetectable, thus indicating the presence of other immunoglobulin isotypes such as IgG and possibly IgA. This is supported by Chernokhvostova et al. who demonstrated that the ' $\mathrm{O}$ ' antibody response after natural infection is comprised of $\operatorname{IgM}, \operatorname{IgG}$ and $\operatorname{IgA}$, while the response to artificial immunization with killed cells is comprised exclusively of IgM. ${ }^{15}$

Only $10 \%$ of our specimens demonstrated a fourfold or greater reduction in 'H' antibody titre after 2-ME treatment. This is in sharp contrast to the findings of several recent publications. ${ }^{10-13}$ It is possible that most of our subjects had been exposed to Salmonella Typhi in the past and, therefore, launched a IgG-dominant secondary antibody response during their current illness.

Our study had one important difference in design compared to other studies on the modified Widal test using 2-ME. While the other studies looked at specimens from patients with culture-documented typhoid fever only, we chose to test specimens from all febrile patients with a clinical suspicion of typhoid fever. We consider our decision justifiable because blood-cultures are positive in an average of only $61 \%$ of patients of typhoid fever, as shown in a recent systematic literature review. ${ }^{16}$ In fact, no diagnostic test for typhoid fever has proved to be a satisfactory 'gold- 
standard' for evaluating the performance of newer tests, and this has led to an increasing reliance on standardized composite references based on Bayesian statistics. $^{17}$

\section{Conclusion}

The modified Widal test with 2-mercaptoethanol demonstrated a strong $\operatorname{IgM}$ response to Salmonella Typhi ' $\mathrm{O}$ ' antigen in more than two-thirds of our specimens that had ' $\mathrm{O}$ ' and ' $\mathrm{H}$ ' titres $\geq 1: 80$ in the Standard Widal test. Since $\operatorname{IgM}$ is considered an indicator of current or recent infection, this low-cost modification of the Widal test has the potential to increase the specificity and acceptability of this widely used investigation.

\section{References}

1. Pegues DA, Miller SI. Salmonellosis, Chapter 190. In: Harrison's Principles of Internal Medicine. 19th ed. Kasper DL, Fauci AS, Hauser SL, Longo DL, Jameson JL, Loscalzo J, Eds. (McGraw-Hill, New York) 2015. p. 1049-55.

2. World Health Organization. Background document: the diagnosis, treatment and prevention of typhoid fever.

3. WHO/V\&B/03.07. WHO, Geneva, Switzerland (2003).

4. John J, Van Aart CJC, Grassly NC (2016) The Burden of Typhoid and Paratyphoid in India: Systematic Review and Meta-analysis. PLoS Negl Trop Dis. 10(4):e0004616. doi:10.1371/journal.pntd.0004616

5. Sinha A, Sazawal S, Kumar R, et al. Typhoid fever in children aged less than five years. Lancet. 1999;354:7347.

6. Crump JA, Sjölund-Karlsson M, Gordon MA, Parry CM. 15 July 2015. Epidemiology, clinical presentation, laboratory diagnosis, antimicrobial resistance, and antimicrobial management of invasive Salmonella infections. Clin Microbiol Rev. doi:10.1128/CMR.0000215.

7. Widal FM. Sérodiagnostic de la fièvre typhoïde. Bull Soc Med Hop Paris. 1896;13:561-6.

8. Olopoenia LA, King AL. Widal agglutination test - 100 years later: still plagued by controversy. Postgrad Med J. 2000;76:80-84.

9. Onyekewere CA. Typhoid fever: Misdiagnosis or overdiagnosis. Niger Med Pract. 2007;51:76-9.

10. Jhaveri KN, Nandwani SK, Mehta PK, Surati RR, Parmar BD. False positive modified Widal test in acute malaria. $J$ Assoc Physicians India. 1995;43:754-5.

11. Pai AP, Koppikar GV, Despande S. Role of modified Widal test in the diagnosis of enteric fever. $J$ Assoc Physicians India. 2003;51:9-11.

12. Rao BN. An evaluation of modified Widal test in the diagnosis of enteric fever. J Indian Med Assoc. 1989;87:179-80.

13. Rattan A, Maheshwari V, Maheshwari NK, Malik A, Malik MA. Application of modified Widal test in specific diagnosis of enteric fever. Indian Pediatr. 1990;27:295-7.

14. Sendil KK, Prakash R, Lakshminarayana SA and Sangeetha S. 2016. Significance of Modified Widal Test with Conventional Widal Test in the Diagnosis of Enteric Fever. Int J Curr Microbiol App Sci. 5(3):605-609. doi: http://dx.doi.org/10.20546/ijcmas.2016.503.070

15. Kok TW, Worswick D, Gowans E. Some serological techniques for microbial and viral infections, Chapter 9. In: Mackie \& McCartney Practical Medical
Microbiology. 14th ed. Collee JG, Fraser AG, Marmion BP, Simmons A, Eds. (Churchill Livingstone, New Delhi) 1996. p. 179-204.

16. Chernokhvostova E, Luxemburg KI, Starshinova V, Andreeva N And German G. Study on the Production of IgG-, IgA- and IgM-Antibodies to Somatic Antigens of Salmonella typhi in Humans. Clin Exp Immunol. 1969;4:407-21.

17. Mogasale V, Ramani E, Mogasale VV, Park JY. What proportion of Salmonella Typhi cases are detected by blood culture? A systematic literature review. Ann Clin Microbiol Antimicrob. (2016)15:32. doi:10.1186/s12941016-0147-z.

18. Storey HL, Huang Y, Crudder C, Golden A, de los Santos T, Hawkins K (2015) A Meta-Analysis of Typhoid Diagnostic Accuracy Studies: A Recommendation to Adopt a Standardized Composite Reference. PLoS ONE. 10(11): e0142364. doi:10.1371/journal.pone.0142364.

How to cite this article: Agarwal RK, Chatterjee B, Mittal G, Bhatla T, Agarwal A. Modified Widal test using 2-mercaptoethanol for detecting anti-salmonella IgM in febrile patients. Indian J Microbiol Res. 2018;5(3):355-357. 